\title{
$\begin{array}{r}\text { WAGENINGEN } \\ \text { UNIVERSITY \& RESEARCH } \\ \hline\end{array}$
}

\section{Need for clean water and recirculation to reduce emissions of plant protection products from soilless cultivation}

Vermeulen, T., van Os, E. A., van der Linden, A. M. A., \& Wipfler, E. L.

This is a "Post-Print" accepted manuscript, which has been published in "None"

This version is distributed under a non-commercial no derivatives Creative Commons (c) $(1) \Theta($ (CC-BY-NC-ND) user license, which permits use, distribution, and reproduction in any medium, provided the original work is properly cited and not used for commercial purposes. Further, the restriction applies that if you remix, transform, or build upon the material, you may not distribute the modified material.

Please cite this publication as follows:

Vermeulen, T., van Os, E. A., van der Linden, A. M. A., \& Wipfler, E. L. (2017). Need for clean water and recirculation to reduce emissions of plant protection products from soilless cultivation. In Proceedings of the ICESC2015: Hydroponics and Aquaponics at the Gold Coast (pp. 87-93). (Acta Horticulturae; Vol. 1176). International Society for Horticultural Science. DOI:

10.17660/ActaHortic.2017.1176.12

You can download the published version at:

https://doi.org/10.17660/ActaHortic. 2017.1176.12 


\title{
NEED FOR CLEAN WATER AND RECIRCULATION TO REDUCE EMISSIONS OF PLANT PROTECTION PRODUCTS FROM SOILLESS CULTIVATION
}

\author{
VERMEULEN T. ${ }^{1}$, VAN OS E.A. ${ }^{1}$, VAN DER LINDEN A.M.A. ${ }^{2}$, WIPFLER E.L. ${ }^{3}$ \\ Wageningen UR Greenhouse Horticulture, P.O. Box 644, 6700 AP, Wageningen, the \\ Netherlands. \\ E-mail: erik.vanos@wur.nl \\ ${ }^{2}$ RIVM, PO Box 1, 3720 BA Bilthoven, the Netherlands. \\ ${ }^{3}$ Wageningen UR Alterra P.O. Box 47, 6700 AA Wageningen, the Netherlands.
}

Soilless cultivation suggests a closed system of water flows, of which (drip) irrigation, evaporation and - in more high-tech systems - condensation water are the main flows. However, in practice growers discharge water during the process of filter cleaning and actively discharge water due to high levels of sodium or contamination with chemical or biological components. On average in the Dutch greenhouse situation $2-5 \%$ of the annual irrigated water is discharged, spread over the year. These discharges lead to pollution of surface water with nutrients as well as (residues of) plant protection products (PPPs). This awareness led in 2008 to the start of a working group that aimed to develop an risk evaluation tool for pesticide authorisation in Europe. The evaluation tool consists of a modelled approach for determining expected concentrations in surface water based on a reference scenario per crop i.e. a description of an actual situation including the technical layout of the glasshouse, the climatological year and the receiving ditch.

For two currently registered PPPs that are used in spray applications, the annual emission to surface water was calculated using different scenarios. As scenarios, the substrate-based rose production and pot plant production were selected in combination with water sources of ranging sodium concentration that commonly occur and are used in The Netherlands. Sodium was found to be the only quantifiable argument for growers for active discharge, and therefore it was used as leading principle for discharge in the water flow model. Water discharge was found to range from 80 to $700 \mathrm{~m}^{3} / \mathrm{ha} /$ year, leading to Nitrogen emission of 17 to $149 \mathrm{~kg} \mathrm{~N} / \mathrm{ha} /$ year. The emission of PPP's in these scenarios amounted to $0.02-3 \%$ of the total active substance that was applied.

KEY WORDS: Pesticides, covered crops, substrate cultivation, risk assessment

\section{INTRODUCTION}

Since systematic monitoring of surface water quality began in the 90's, findings of plant protection products (PPP) in surface water as well as elevated concentrations of $\mathrm{N}$ and $\mathrm{P}$ correlated with the occurrence of greenhouse cultivation in The Netherlands (www.bestrijdingsmiddelenatlas.nl). The ruling policy notion that greenhouses do not emit water was challenged over the following year. Given the EU's intensification on environmental policy, The Netherlands had to revisit the perspective on emissions from greenhouses, both for emission of nutrients as for PPP. While nutrient policies in agriculture are mainly nationally organised though with EU norms, registration of PPP has both a national component and a EU component. This paper quantifies the emission of two PPP, but given the calculated water flows needed for these calculations, also the emission of nutrients can be calculated. 
In 2008 a working group was established to understand the basic characteristics of water fluxes in greenhouses and model the expected emission of PPP (Vermeulen, et al., 2010). The working group focussed on both soil bound production and substrate system. In this paper we limit ourselves to substrate systems. The working group identified water as the dominant carrier for the emission of PPP to surface water, and therefore made an inventory of the typical water streams in greenhouses. Figure 1 gives the overview of water flows in a substrate-based growing system.

Given this number of emission streams, the working group targeted the main flows with impact on surface water for further modelling: being Discharge and Filter rinsing water. To quantify the flow, the working group used the WATERSTREAMS model (Voogt et al., 2012) and developed a fate model (see Material and Methods). This combination of models was adopted within the EU-context as possible instrument in the evaluation of environmental impact in the registration procedure.

In order to get an understanding of the emission caused by a typical application regime, two PPP were used for further calculations. The products were used as spray application in the production of pot plants and cut roses - both on substrate. These products were selected based on the interest of commercial partners.

\section{MATERIALS AND METHODS}

The modelled approach consists of two models: WATERSTREAMS and a substance fate model (Vermeulen et al., 2010; Voogt et al, 2012). The WATERSTREAMS model calculates the water flows as described in figure 2. The figure gives the volumes of the different bodies $\left(\mathrm{m}^{3}\right)$ and the directions of the water flow within the system. In this figure PPP is added by spray application, while an application through the drip system would be depicted as application in the mixing tank. Upon spray application PPP enters the recirculation stream through run off to the substrate, interception of the spray by the substrate and the introduction of PPP in the recirculation water through the condensation and evaporation flow from both crop and greenhouse floor.

The Substance Fate model describes the fate aspects of PPP in the different bodies. Fate is the breakdown of the product or otherwise removal of the product from the system based on its chemical properties. Relevant factors are Temperature, plant uptake, Volatilisation, dissipation from the crop canopy, Time (flow speed), light (in case of light-sensitive substances). The products used in this study were identified by their molar mass, Kom (equilibrium organic matter sorption constant of the substance, (m3 kg-1)), Vapour pressure, Kow (octanol water partitioning coefficient), Solubility, diffusion in air and DT50 in water. For confidentiality reasons the values of the used substances are not given. With similar DT50 values, the substances differed in volatility and sorption to organic matter: substance A: volatile and low sorption, substance B: less volatile and high sorption. Table 1 gives the dosage and application frequency.

The WATERSTREAMS model calculates emission based on greenhouse practices where standard filter rinsing is done using recirculation water and discharge is a function of Sodium build-up in the water (Os et al., 2012). For the calculations a four scenarios are used for both pot plants and cut roses. Scenarios 1 and 2 differ in the quality of the fertilises used in terms of the concentration of sodium in them. Scenario 3 is an extreme coastal situation with high levels of sodium in the rain water. Scenario 4 is not sodium-driven, but gives the water flows for a situation where a grower uses the allowed volumes of $\mathrm{N}$ that may be discharged (2012). The rain 
fall, temperature and irradiation is taken from weather data of a dry year (1997), which leads to relatively high usage of poorer (more sodium rich) water sources, making the scenarios almost worst case. Such a 'realistic worst case' approach is common for evaluation of PPP in EU. Tabel 2 gives the data of the water flows in the described scenarios.

\section{RESULTS \\ Rose}

The scenarios given in table 2 lead to a water flux to surface water as given in figure 3 . Typically the situation with no active discharge only has the frequent flux of filter rinsing water. In the different scenarios the accumulation of sodium leads to infrequent discharges of recirculation water in order to lower the concentration. As shown, scenario 4 gives the grower the ability to discharge at will, while using the allowed volumes of discharge. The moment of discharge is taken after active treatment.

These water fluxes in turn lead to a cumulative mass flux of PPP as shown in figure 4 . The first application of product A was done at day 200. As a result, the emission started from that day on through the filter rinsing water. The moment and volumes of active discharge was then instrumental for further emission. In scenario 4 the high emission was due to a full discharge of the recirculation water at that point in time. Table 3 gives the mass fluxes of the emission in $\mathrm{kg}$ as wel as in \%. For these rose scenarios product A was emitted between 0.3 and $1.1 \%$ of total applied product, while product $\mathrm{B}$ was emitted at rates of 1.3 and $3.3 \%$.

\section{Pot plant}

Similarly for the pot plant scenario figure 5 gives the cumulative fluxes of water emitted to the surface water and the mass of product A in this flow. Product B is not applied on this crop, and so not used for further calculation. The figures show that this given pot plant production discharges less than a substrate-based rose production. The legally allowed volumes that growers can discharge (scenario 4) is set at a higher level than can be justified by a modelled approach based on sodium accumulation (scenario 1,2 and 3). Scenario 2 gave the same results as scenario 1. In these scenarios the mass flux of product A to surface water follows the same trend as the water flux. Also here product was applied at day 200, leading to emissions from that day on.

The end results of emission of PPP is given in table 3. In pot plants the emission is much lower due to the lower levels of water flow to the surface water as well as binding in the substrate. Here emissions are calculated of $0.02 \%$ up to $0.14 \%$ of the total active ingredient applied.

Using concentration of $14 \mathrm{mmol} \mathrm{N}$ and $1.3 \mathrm{mmol} \mathrm{P}$ in the recirculation water, the emissions of fertilisers can be calculated. Table 4 gives the results of the total calculated annual emission of nutrients. The emissions range from 17 up to $98 \mathrm{~kg} \mathrm{~N}$ in pot plants and 46 up to $149 \mathrm{~kg} \mathrm{~N}$ in rose production. For phosphor these figures are $3.1 \mathrm{~kg}$ up to $18.3 \mathrm{~kg}$ for pot plants and $8.5 \mathrm{~kg}$ up to $27.6 \mathrm{~kg}$ for rose production.

\section{CONCLUSION AND DISCUSSION}

The results suggest high emission of both products A and B in rose production, while the emission in the pot plant scenarios is much lower. However, compared to the current evaluation of pesticides these calculated emission are significantly higher than used for registration 
purposes. Current EU methodology for evaluation accepts a $0,1 \%$ drift of the applied active ingredient, leading to a lower actual emission to surface water depending on the scenario used for the risk evaluation. Emissions of $\mathrm{N}$ and $\mathrm{P}$ are easier to quantify in practice, so that these values can be compared with surveys - these values are within the ranges of what can be expected in practice.

The PPP used in this paper were introduced via spray application. Application through the recirculation water, such as imidacloprid, was found to give higher emission of $0.1 \%$ (wet year, large basin) up to $15 \%$ (dry year) (Vermeulen et al., 2010).

To further develop the models used in this report for evaluation purposes of PPP in the Netherlands, similar calculations were compared to data from experimental setup (Maas et al., 2015). In the experimental setup lower emissions were found then expected based on the model. The model assumes values for plant uptake, DT50 and absorption to the system (substrate and materials), which are commonly used in open field production. However, these values may differ in greenhouse context with higher temperatures, higher evapotranspiration, nutrient solution (instead of water) and materials of which the interaction with PPP is not known. The current assumptions in the model, therefore, are expected to overestimate the emission of PPP to surface water.

Crucial in reducing emission is using high quality irrigation water and re-using the flow of filter rinsing water. Since emission of PPP (and fertilisers) is directly linked to water discharge, strategies for better recirculation need to be developed (Os et al., 2012). Technically possibilities already allow for almost complete recirculation. Using a clean (biological and chemical) water source as well as buffers for re-using of streams can help growers to become more efficient with their water.

\section{ACKNOWLEDGEMENTS}

The authors wish to thank the ministries of Economic Affairs and of Infrastructure and the Environment for supporting the project. The authors wish to thank the members of the working groups 2008 and 2009, Erwin Roex, Ynze Stienstra, Roel Kruijne, Rik de Werd, Jan Huijsmans, Rob Meijer, Marieke van der Staaij and Wim Voogt for their contribution.

\section{LITERATURE CITED}

Maas, B. van der; Staaij, M. van der; Eveleens, B.; Beerling, E.; Os, E. van; Ruijven J. van; Wipfler, L. 2015. Toetsing emissiemodel substraatteelt. Rapport GTB-1340. Wagening UR Greenhouse Horticulture

Os EA. Van; Vermeulen, T.; W. Voogt. 2012. Good water quality to improve an efficient use of water and nutrients in soilless cultivation. ISHS conferense Shanghai 2012

Vermeulen, T; Os, E.A. van; A.M.A. van der Linden. 2010. Emissions of plant protection products from glasshouses to surface water in The Netherlands. Rapport GTB-1002. RIVM Rapport: 607407001

http://www.bestrijdingsmiddelenatlas.nl/ 
Voogt et al 2012

Tables

Table 1: The products were applied according to manufacturors' advise at the following rate:

\begin{tabular}{|l|l|l|l|}
\hline & dosage & $\begin{array}{l}\text { Frequency of spray } \\
\text { application }\end{array}$ & Total volume applied \\
\hline $\begin{array}{l}\text { product } \\
\text { A }\end{array}$ & $\begin{array}{l}0.012 \mathrm{~kg} \text { a.i.* / } \\
\text { ha }\end{array}$ & Weekly in July & $\begin{array}{l}0.024 \mathrm{~kg} \text { (rose), 0.36 kg (pot } \\
\text { plants) }\end{array}$ \\
\hline $\begin{array}{l}\text { product } \\
\text { B }\end{array}$ & $1.5 \mathrm{~kg}$ a.i. / ha & Weekly year round & $75 \mathrm{~kg}$ (rose) \\
\hline
\end{tabular}

*active ingredient

Table 2: scenarios used for calculating water streams and eventual emission of PPP to surface water.

\section{Pot plant 1}

Rain (m3/ha)

uptake (m3/ha)

irrigation

(m3/ha)

Drain (m3/ha)

Condens water

(m3/ha)

Discharge

(m3/ha)

Filter rins

(m3/ha)

Leakage

(m3/ha)

total waste water

Bassin water

RO water

kg N/ha/year
6439

5457

7275

1819

794

0

79

109

188

4833

0

17
Pot
plant

Pot

plant 3

coast

6439

5457

7275

1819

794

0

79

109

188

4833

0

17

6439

5457

7275

1819

794

40

79

109

188

4873

0

26 $\mathbf{0 , 3}$

0,1

0,1

519

7636

1240

51

0,1

fertiliser(mmol

$\mathrm{Na} / \mathrm{l}$ )

Rain basin $\left(\mathrm{m}^{3}\right)$

$\mathrm{Na}$ rain water

$\mathrm{Na}$ in $\mathrm{RO}$ water

drain percentage

$\begin{array}{llll}\mathbf{2 5 0 0} & \mathbf{2 5 0 0} & \mathbf{1 5 0 0} & \mathbf{2 5 0 0} \\ 0,1 & 0,1 & \mathbf{0 , 5} & 0,1 \\ \mathbf{0 , 1} & \mathbf{0 , 1} & \mathbf{0 , 1} & \mathbf{0 , 1} \\ \mathbf{2 5 \%} & \mathbf{2 5 \%} & \mathbf{2 5 \%} & \mathbf{5 0 \%}\end{array}$

$25 \%$

2500

1500

2500

2500

0,1

0,5

$\mathbf{0 , 8 5}$

0,1

$\mathbf{0 , 1}$

0,1

$\mathbf{0 , 1}$

1,43

$50 \%$ $\mathbf{5 0 \%}$

$25 \%$

$\mathbf{5 0 \%}$

Table 3: calculated cumulative emission of PPP given the different scenarios and different crops.

\begin{tabular}{|l|l|l|l|l|c|c|c|}
\hline & & & \multicolumn{5}{|c|}{$\begin{array}{l}\text { Calculated cumulative emission to surface water per scenario }(\mathrm{kg} \\
\text { and \%) }\end{array}$} \\
\hline & & $\begin{array}{l}\text { Dosage } \\
\text { (kg a.i. / } \\
\text { ha) }\end{array}$ & $\begin{array}{l}\text { Applied } \\
(\mathrm{kg})\end{array}$ & 1 & 2 & 3 & 4 \\
\hline Rose & Product A & 0.012 & 0.024 & $0.610^{-4}$ & $1.410^{-4}$ & $1.410^{-4}$ & $2.610^{-4}$ \\
\hline
\end{tabular}




\begin{tabular}{|l|l|l|l|r|r|r|r|}
\hline & & & & $(0.3 \%)$ & $(0.6 \%)$ & $(0.6 \%)$ & $(1.1 \%)$ \\
\hline & Product B & 1.5 & 75 & $1(1.3 \%)$ & $1.75(2.3 \%)$ & $2.45(3.3 \%)$ & $1.5(2.0 \%)$ \\
\hline $\begin{array}{l}\text { Pot } \\
\text { plants }\end{array}$ & Product A & 0.012 & 0.034 & $0.810^{-5}$ & & $1.910^{-5}$ & $4.810^{-5}$ \\
& & & $(0.02 \%)$ & & $(0.06 \%)$ & $(0.14 \%)$ \\
\hline
\end{tabular}

Table 4: calculated emission of $\mathrm{N}$ and $\mathrm{P}$ given the different scenarios $(\mathrm{kg})$

\begin{tabular}{|r|r|c|c|c|c|}
\hline & scenario & $\mathbf{1}$ & $\mathbf{2}$ & $\mathbf{3}$ & $\mathbf{4}$ \\
\hline $\begin{array}{r}\text { Rose } \\
\text { plant }\end{array}$ & $\mathrm{N}$ & 46 & 96 & 131 & 149 \\
\hline Rose & $\mathrm{N}$ & 17 & 17 & 25 & 98 \\
\hline $\begin{array}{r}\text { Pot } \\
\text { plant }\end{array}$ & $\mathrm{P}$ & 8.5 & 17.8 & 24.4 & 27.6 \\
\hline
\end{tabular}

\section{Figures}

\section{Glasshouse - hydroponic cultivation: Production}

\section{space}

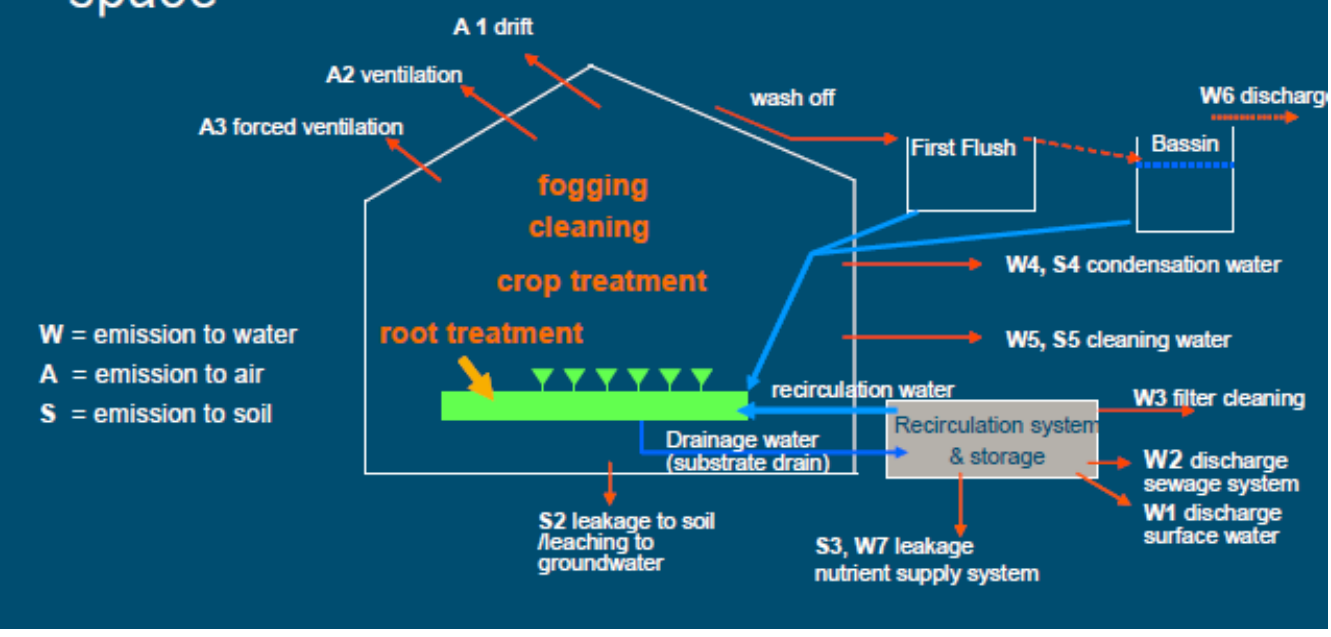

Figure 1: fluxes of water leaving the greenhouse 


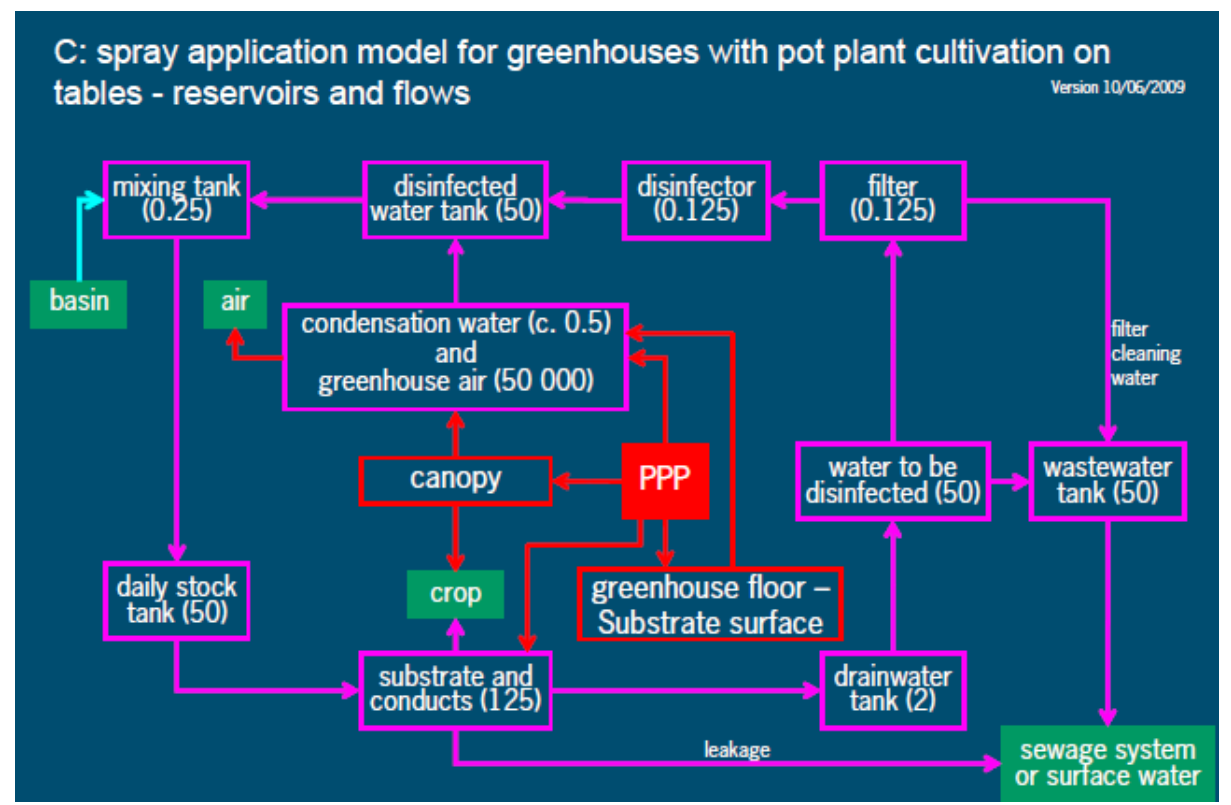

Figure 2: Schematic representation of the system for crop application. Variant in which the root compartment may be directly exposed. (volumes of bodies in $\mathrm{m}^{3}$ ).

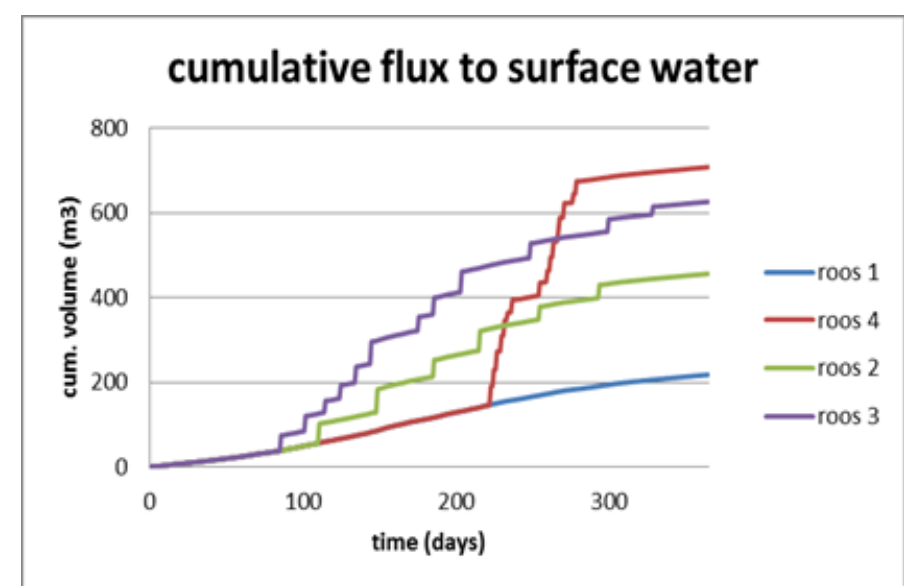

Figure 3: sum of discharge water and filter rinsing water in rose production given 4 different scenarios. The discharge water contains products $\mathrm{A}$ and $\mathrm{B}$.
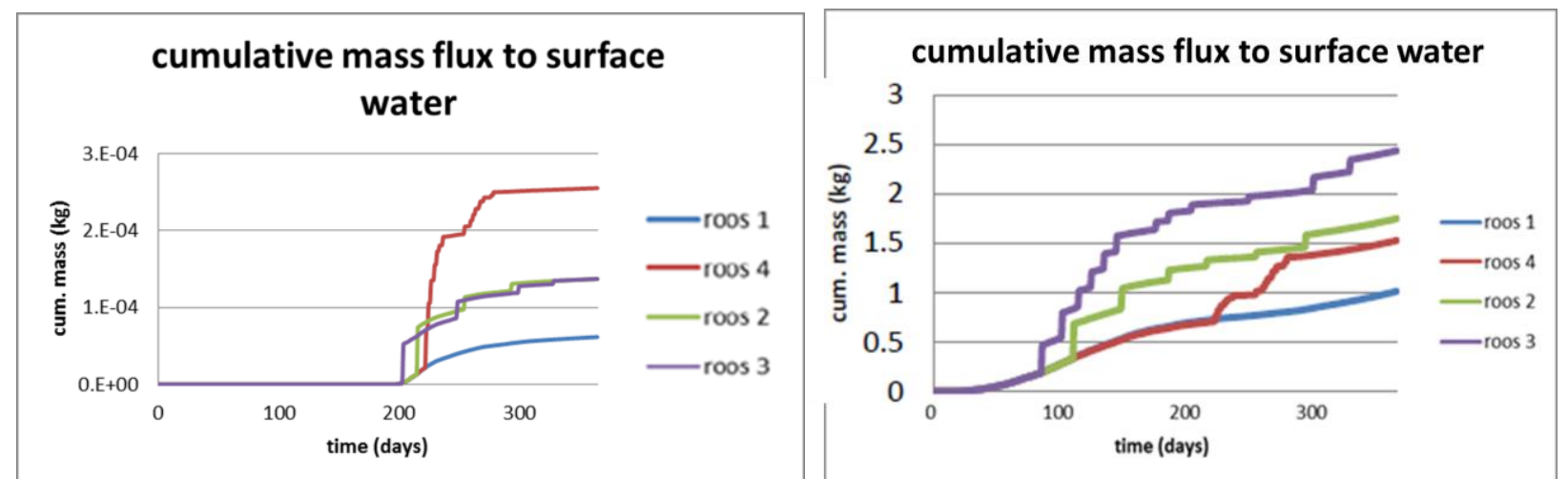

Figure 4: cumulative mass flux of product A (left) and product B (right) from the greenhouse to surface water. 


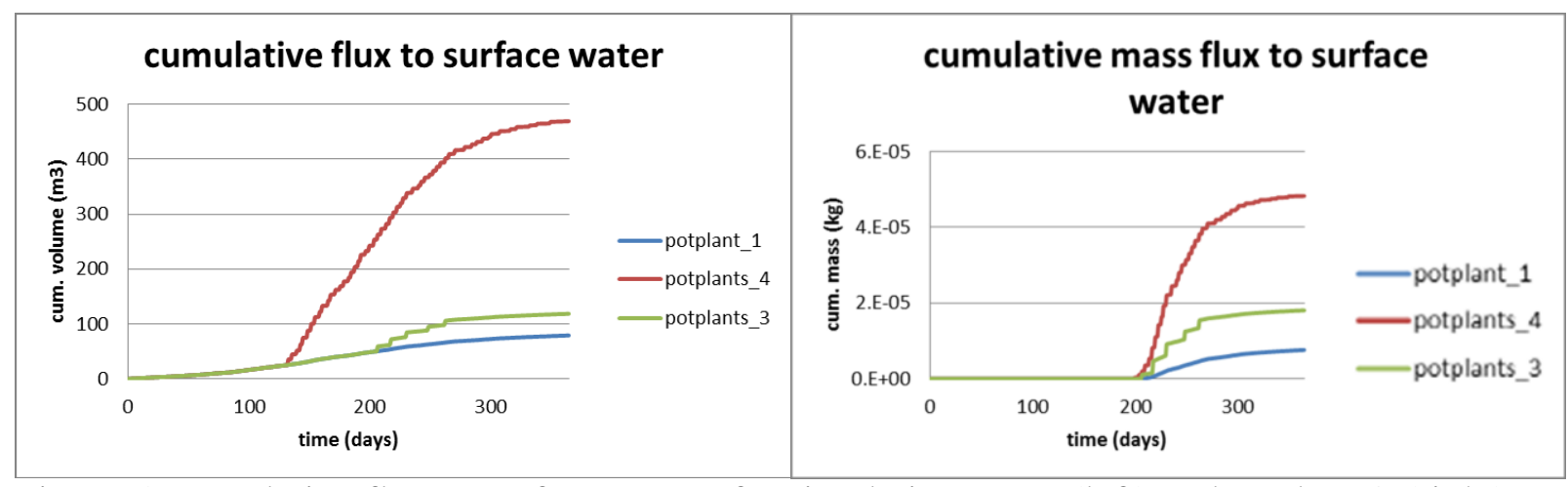

Figure 5: cumulative flux to surface water of recirculation water (left) and product A (right) 